\title{
The gene expression pattern induced by high plating density in cultured bovine and buffalo granulosa cells might be regulated by specific miRNA species
}

\author{
Vengala Rao YENUGANTI'), Vijay Simha BADDELA ${ }^{1)}$, Anja BAUFELD ${ }^{2)}$, Dheer SINGH ${ }^{1)}$ and \\ Jens VANSELOW ${ }^{2)}$ \\ ${ }^{1)}$ Molecular Endocrinology Laboratory, Animal Biochemistry Division, National Dairy Research Institute, Karnal 132001, \\ India \\ ${ }^{2)}$ Institute of Reproductive Biology, Leibniz Institute for Farm Animal Biology (FBN), 18196 Dummerstorf, Germany
}

\begin{abstract}
Precise regulation of cell type-specific gene expression profiles precedes the profound morphological reorganization of somatic cell layers during folliculogenesis, ovulation and luteinization. Cell culture models are essential to the study of corresponding molecular mechanisms of gene regulation. In a recent study, it was shown that an increased cell plating density can largely change gene expression profiles of cultured bovine granulosa cells. In our present study, we comparatively analyzed cell plating density effects on cultured bovine and buffalo granulosa cells. Cells were isolated from small- to medium-sized follicles $(2-6 \mathrm{~mm})$ and cultured under serum-free conditions at different plating densities. The abundance of selected marker transcripts and associated miRNA candidates was determined by quantitative real-time RT-PCR. We found in both species that the abundance of CYP19A1, CCNE1 and PCNA transcripts was remarkably lower at a high plating density, whereas $V N N 2$ and $R G S 2$ transcripts significantly increased. In contrast, putative regulators of CYP19A1, miR-378, miR-106a and let-7f were significantly higher in both species or only in buffalo, respectively. Also miR-15a, a regulator of CCNE1, was upregulated in both species. Thus, increased plating density induced similar changes of mRNA and miRNA expression in granulosa cells from buffalo and cattle. From these data, we conclude that specific miRNA species might be involved in the observed densityinduced gene regulation.
\end{abstract}

Key words: Cell culture, Cell density, microRNA, Real-time PCR

(J. Reprod. Dev. 61: 154-160, 2015)

D evelopment and maturation of oocytes occurs within the ovarian follicle and are supported by surrounding somatic cells of the cumulus and granulosa cell layer. Under the control of folliclestimulating hormone (FSH), granulosa cells (GCs) start secreting considerable amounts of estradiol [1]. As the follicle approaches ovulation, the density of GCs increases, but after the preovulatory luteinizing hormone (LH) surge, proliferation ceases, and GCs transform into progesterone-producing luteal cells [2, 3]. Corpus luteum formation is associated with extensive morphological and physiological changes as well as with profound alterations of GC mRNA expression profiles [2, 4]. Most of the genes involved in follicular growth and granulosa cell proliferation and function like CYP19A1, FSHR, LHCGR, PCNA, and CCNE1, encoding aromatase, FSH receptor, $\mathrm{LH}$ receptor, proliferating cell nuclear antigen and cyclin E1, respectively, are downregulated following the LH surge, whereas, for example, VNN2 and RGS2, encoding vanin-2 (vascular

Received: September 30, 2014

Accepted: December 25, 2014

Published online in J-STAGE: February 3, 2015

C 2015 by the Society for Reproduction and Development

Correspondence: J Vanselow (e-mail: vanselow@fbn-dummerstorf.de), or D Singh (e-mail: drdheer.singh@gmail.com)

This is an open-access article distributed under the terms of the Creative Commons Attribution Non-Commercial No Derivatives (by-nc-nd) License $<$ http://creativecommons.org/licenses/by-nc-nd/3.0/>. non-inflammatory molecule 2) and regulator of G-protein signaling 2 , which are involved in vascularization, inflammatory processes, oxidative stress, and in membrane signaling pathways around ovulation, respectively, are upregulated [5-9].

Several in vitro models have been published to study different stages and functional facets of folliculogenesis and luteinization [10-12]. These models are essential to elucidate the underlying molecular mechanisms of gene regulation. According to recent studies, high-density plating of bovine GCs alters the ratio of estrogenic to progestagenic enzyme gene expression [13] and the expression of other marker genes, thus suggesting the induction of a gene expression pattern similar to early post-LH stages of luteinization [14]. Transcript abundance levels are regulated in different ways, such as transcriptional regulation via cis-acting promoter, enhancer and silencer elements and posttranscriptional regulation as mRNA stability, whereby microRNA (miRNA) species are decisively involved. MicroRNAs (miRNAs) are short noncoding RNAs that regulate the levels of mRNAs by binding within their 3' UTR, thus inducing degradation [15]. Different studies have shown that miRNAs are involved in diverse cellular functions like development, growth, proliferation, differentiation and apoptosis. Besides other proteins, DICER and RISC protein complexes are usually involved in miRNA actions [15]. In the ovary, knockdown of DICER leads to dysfunction of folliculogenesis, oocyte maturation and the ovulation process [16-19]. For miR-224, a vital role in TGF- $\beta$-mediated cell 
proliferation, aromatase expression and estradiol production in mouse GCs has been shown [20], as in the case of miR-383, which affects the production of estradiol and aromatase expression. In porcine granulosa cells, it was demonstrated that miR-378 is involved in the regulation of ovarian estradiol production [21]. In addition to the abovementioned miRNA species, high levels of let-7f in breast cancer cells are also significantly correlated with decreased aromatase protein, and a specific binding site for this miRNA species could be demonstrated in the 3'UTR of CYP19A1 transcripts [22]. The expression of miR-15a, which induces apoptosis in leukemic cell lines through the negative regulation of the anti-apoptotic gene $B C L 2$ [23], is downregulated in the majority of patients with chronic lymphocytic lymphoma [24]. In addition to these functions, miR-15a is also involved in the regulation of proliferation [25]. This study showed that the transcription factor E2F1 activated the expression of miR-15a, miR-16-1, miR-15b, and miR-16-2, by binding to their respective promoters. On the other hand, miR-15a/b inhibits the expression of $C C N E 1$, which in turn is the direct transcriptional target of E2F1 and pivotal for the G1/S transition. Ectopic expression of miR-15 inhibits the G1/S transition, and inhibition of miR-15 expression increases E2F1-induced upregulation of CCNE1 mRNA transcript levels [25].

In the present study, we comparatively analyzed effects of different plating densities on cultured bovine and buffalo GCs based on mRNA levels of selected marker transcripts, and as a first approach to elucidation of the underlying molecular mechanisms, we also determined concentrations of possibly relevant miRNA species.

\section{Materials and Methods}

\section{Culture of granulosa cells}

Granulosa cells from bovine and buffalo small- to medium-sized follicles (2-6 mm diameter) were cultured according to previous studies $[14,26]$. Briefly, GCs of both species were plated on 24-well plates at high (buffalo and cattle: $1 \times 10^{6}$ cells per well, corresponding to $5 \times 10^{3}$ cells $/ \mathrm{mm}^{2}$ ) and low density (buffalo, $2 \times 10^{5}$ cells per well or cattle, $1 \times 10^{5}$ cells per well, corresponding to $0.5 \times 10^{3}$ cells $/ \mathrm{mm}^{2}$ (cattle) or $1 \times 10^{3}$ cells $/ \mathrm{mm}^{2}$ (buffalo), respectively) for the initial $48 \mathrm{~h}$ in $\alpha$-MEM and DMEM for cattle and buffalo, respectively, containing $1 \mathrm{ng} / \mathrm{ml} \mathrm{FSH}$ and $1 \mathrm{ng} / \mathrm{ml}$ IGF-I (both Sigma-Aldrich, Steinheim, Gamany). Subsequently, this basal medium was replaced with stimulating media containing $25 \mathrm{pg} / \mathrm{ml}$ and $20 \mathrm{pg} / \mathrm{ml} \mathrm{FSH}$ for buffalo and bovine GCs, respectively, and $50 \mathrm{ng} / \mathrm{ml} \mathrm{IGF-I.} \mathrm{Cells}$ were incubated for an additional $48 \mathrm{~h}$ and RNA was isolated for the analysis of mRNA and miRNA abundance. The morphology of cultured bovine and buffalo granulosa cells was very similar after 48 h (Fig. 1).

\section{RNA isolation and cDNA synthesis}

Total RNA was isolated from GCs with the mirVana ${ }^{\mathrm{TM}}$ miRNA Isolation Kit (Ambion, USA) as per the manufacturer's instructions. RNA was quantified with a NanoDrop 1000 Spectrophotometer (Thermo Scientific, Bonn, Germany). In cattle, cDNA was prepared with M-MLV reverse transcriptase and RNasin ribonuclease inhibitor (both Promega, Mannheim, Germany) using oligo-(dT) primers (2 $\mathrm{ng} / \mu \mathrm{l})$ mixed with random hexamer primers (4 $\mathrm{ng} / \mu \mathrm{l}$; both Roche,
Mannheim, Germany) as described previously [14]. In the case of buffalo GCs, cDNA was prepared with a First Strand cDNA Synthesis Kit (Thermo Scientific, Lithuania) as per the manufacturer's instructions [27]. The prepared cDNA was used for the analysis of transcript abundance by real-time PCR. Preparation of cDNA for miRNA analysis and quantification by real-time PCR were carried out with a miScript PCR Starter Kit (Qiagen, Hilden, Germany).

\section{Real-time PCR}

Quantitative real-time RT-PCR (qPCR) for CYP19A1, VNN2, $R G S 2, P C N A, C C N E 1$ and the housekeeping gene RPLP0 for normalization was performed as described previously $[14,27]$ with gene-specific primers (Table 1). miRNA quantification relative to U6 transcripts was carried out according to the miScript PCR Starter Kit instructions using different miRNA primers (Table 1). Expression of genes was quantified on the basis of $\mathrm{Ct}$ value (delta delta $\mathrm{Ct}$ method). Because the buffalo genome has only partially been published, primer sequences were derived from the cattle genome. Both species, however, are very closely related, and in particular, miRNAs are highly conserved among species.

\section{Statistical analysis}

Data were analyzed by one-way ANOVA. A two-tailed $t$-test was performed to determine the significance using the MS Excel software. All experimental data are presented as the mean \pm SEM of three independent experiments. $\mathrm{P}<0.05$ differences were considered significant.

\section{Results}

\section{Effects of plating density on the abundance of selected marker transcripts}

To evaluate effects of cell plating density on the key gene of estradiol production, CYP19A1, on cell proliferation markers, $P C N A$ and $C C N E 1$, and on selected periovulatory markers of early luteinization, $V N N 2$ and $R G S 2$ transcript abundance was quantified by qPCR. The results showed that CYP19A1, PCNA and CCNE1 expressions were significantly lower at a high plating density as compared with low-cell-density cultures in both species (Fig. 2A, $\mathrm{B}$ and $\mathrm{C}$ ). In contrast, expression of $V N N 2$ and $R G S 2$ transcripts was significantly increased at a high plating density in cattle and buffalo (Fig. 2D and E).

\section{Effects of plating density on the abundance of associated miRNAs}

To elucidate a possible role of miRNA in density-induced CYP19A1 and $C C N E 1$ gene regulation in cultured GCs, we analyzed miRNAs let 7f, mir-378, miR-106a and miR-15a. The data showed that let-7f abundance was significantly higher in high-density cultures in buffalo but not in cattle (Fig. 3C). In contrast, mir-378, miR-106a and miR-15a levels were significantly higher in GCs at a high plating density as compared with a low plating density in both species (Fig. $3 \mathrm{~A}, \mathrm{~B}$ and D). 

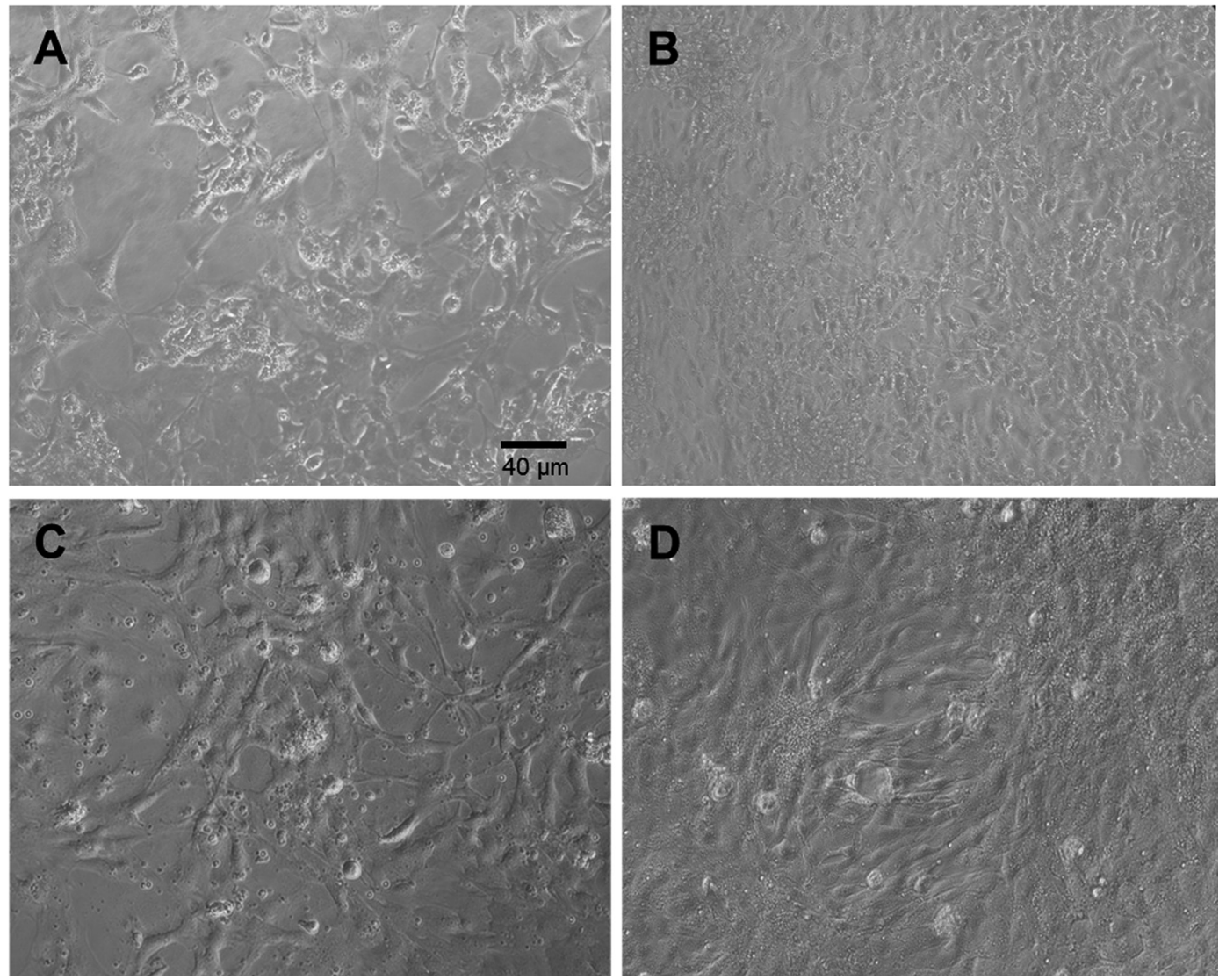

Fig. 1. Bovine and buffalo granulosa cells after 4 days in culture. Bovine granulosa cells cultured at low $\left(0.5 \times 10^{3}\right.$ cells/ $\left.\mathrm{mm}^{2}\right)$ and high density $\left(5 \times 10^{3}\right.$ cells $\left./ \mathrm{mm}^{2}\right)$ are shown in A and B, respectively, whereas granulosa cells from buffalo are shown in $\mathrm{C}$ at a low plating density low $\left(1 \times 10^{3}\right.$ cells $\left./ \mathrm{mm}^{2}\right)$ and in $\mathrm{D}$ at a high plating density $\left(5 \times 10^{3}\right.$ cells/ $\mathrm{mm}^{2}$ ). Photomicrographs of cultured bovine cells were taken with a Nikon TMS- F inverted microscope, whereas those of buffalo cells were taken with a Nikon eclipse Ti microscope.

Table 1. Primers used for transcript quantification by qPCR

\begin{tabular}{ll}
\hline CYP-19A1 Forward (Cattle \& Buffalo) & GCTTTTGGAAGTGCTGAACCCAAGG \\
CYP-19A1 Reverse (Cattle \& Buffalo) & GGGCCCAATTCCAGAAAGTAGCTG \\
PCNA Forward (Cattle \& Buffalo) & GTGAACCTGCAGAGCATGGACTCGT \\
PCNA Reverse (Cattle \& Buffalo) & CGTGTCCGCGTTATCTTCAGCTCTT \\
CCNE1 Forward (Cattle) & CTGCCTGTACTGAACTGGGC \\
CCNE1 reverse (Cattle) & TTGCTCGCATTTTAGGCTGC \\
CCNE1 Forward (Buffalo) & TAAGGAATTGTTGGCCGCCT \\
$C C N E 1$ reverse (Buffalo) & ACATCCCCAGCTTAAATCAGGT \\
$V N N 2$ Forward (Cattle \& Buffalo) & TCCCACAGCTTGGATGAACGTTTTG \\
$V N N 2$ reverse (Cattle \& Buffalo) & TAGGCACTCCAATTCATGGCTGGTG \\
$R G S 2$ Forward (Cattle \& Buffalo) & AAGCCCAGCTGTGGTCAGAAGCATT \\
$R G S 2$ Reverse (Cattle \& Buffalo) & TCTTCACAGGCCAGCCAGAATTCAA \\
$R P L P 0$ forward (Cattle \& Buffalo) & TGGTTACCAACCGTCGCATCTGTA \\
$R P L P 0$ Reverse (Cattle \& Buffalo) & CACAAAGGCAGATGGATCAGCCAAG \\
$m i R-378$ (Cattle \& Buffalo) & ACTGGACTTGGAGTCAGAAGGC \\
Let-7f (Cattle \& Buffalo) & TGAGGTAGTAGATTGTATAGTT \\
$m i R-106 a$ (Cattle \& Buffalo) & AAAAGTGCTTACAGTGCAGGTA \\
$m i R-15 a$ (Cattle \& Buffalo) & TAGCAGCACATAATGGTTTGT \\
U6 (Cattle \& Buffalo) & Primers from miScript PCR Starter Kit \\
\hline
\end{tabular}


A

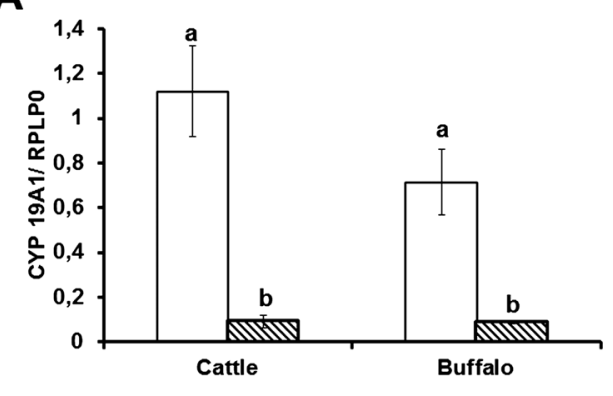

B

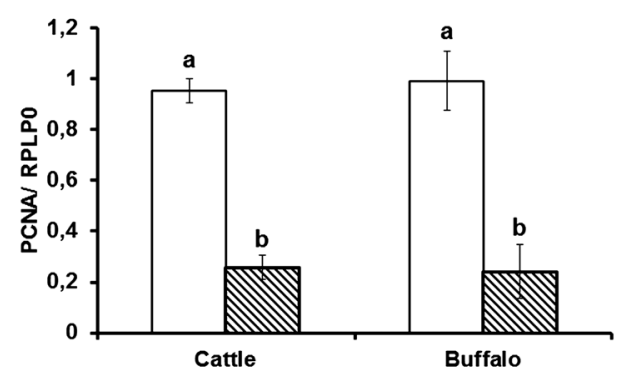

C

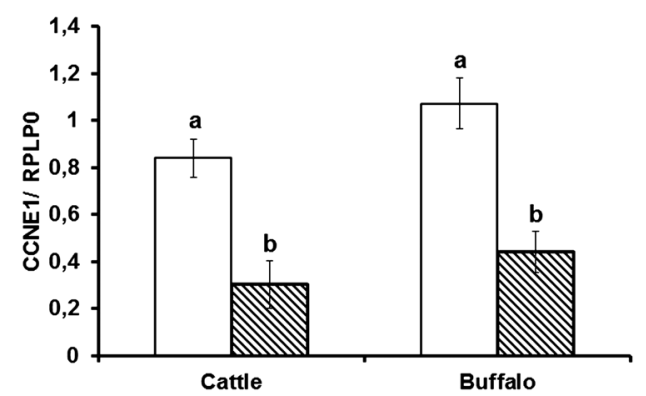

D

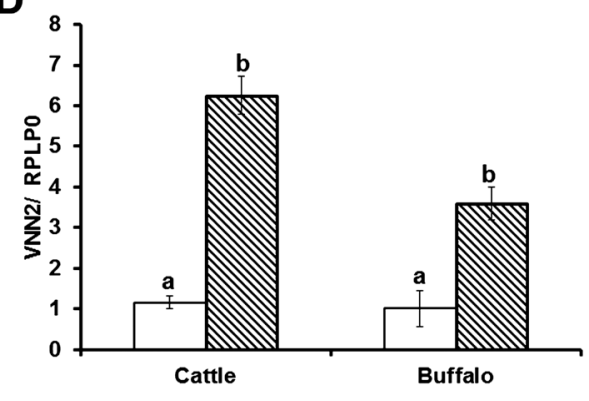

$\mathbf{E}$

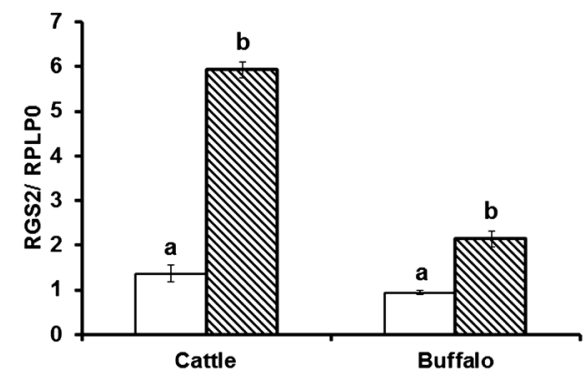

Fig. 2. Effects of cell plating density on the abundance of selected transcripts in cultured granulosa cells from buffalo and cattle. Whereas the abundance of CYP19A1 (A), PCNA (B) and CCNE1 (C) transcripts was considerably lower at high (filled columns) compared with low (empty columns) plating density, VNN2 (D) and $R G S 2$ (E) transcripts were significant increased. Transcript abundance was determined by real-time RT-PCR in granulosa cells plated at high (buffalo and cattle: $5 \times 10^{3}$ cells $/ \mathrm{mm}^{2}$ ) and low density (buffalo, 1 $\times 10^{3}$ cells $/ \mathrm{mm}^{2}$; cattle, $0.5 \times 10^{3}$ cells $/ \mathrm{mm}^{2}$, respectively) after 4 days in culture. The data are indicated as transcript abundance relative to $R P L P 0$ (mean \pm SEM) of three independent experiments. Different letters indicate significant differences at $\mathrm{P}<0.05$ levels.

\section{Discussion}

Cultured granulosa cells from buffalo and cattle adopt a luteinization-like expression pattern at a high plating density

In cultured GCs of both species, considerably lower transcript levels of PCNA, CCNE1 and, in particular of CYP19A1, but higher levels of $V N N 2$ and $R G S 2$ transcripts were observed at a high plating density as compared with a low plating density. As hypothesized in a previous study, these characteristic changes of marker transcripts indicate a luteinization-like gene expression pattern induced by a high plating density of cultured GCs. It has been repeatedly shown that the abundance of CYP19A1 transcripts, encoding P450arom, the key enzyme of estrogen biosynthesis, is rapidly downregulated in the GC layer following the preovulatory LH surge $[5,28,29]$. Also, in various tissue culture models, downregulation of CYP19A1 by $\mathrm{LH} / \mathrm{hCG}$ application has been demonstrated $[14,26]$. In addition, downregulation of $P C N A$, which is a sensitive marker for cell proliferation [30], and of CCNE1 transcripts is also well in accordance with the fact that cells of the GC layer largely cease proliferation during the process of luteinization. It has also been shown in vitro that low 
A

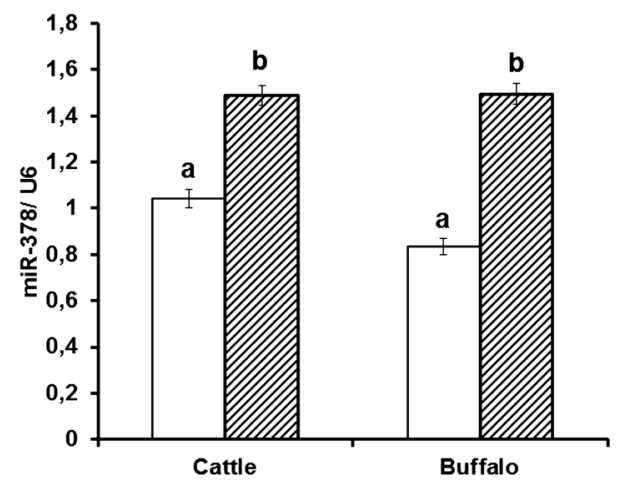

C

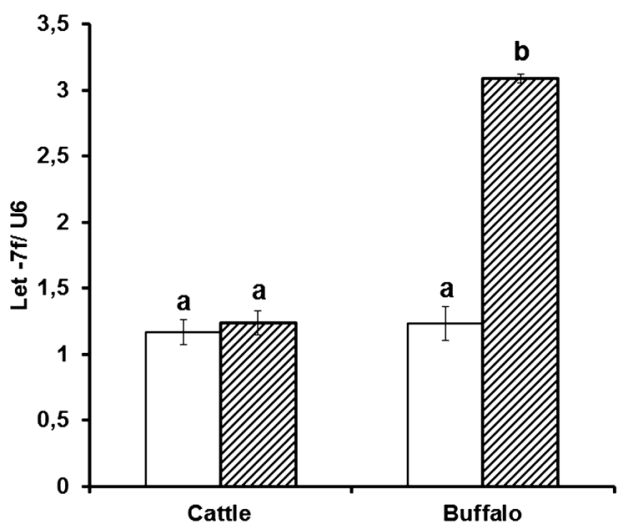

B

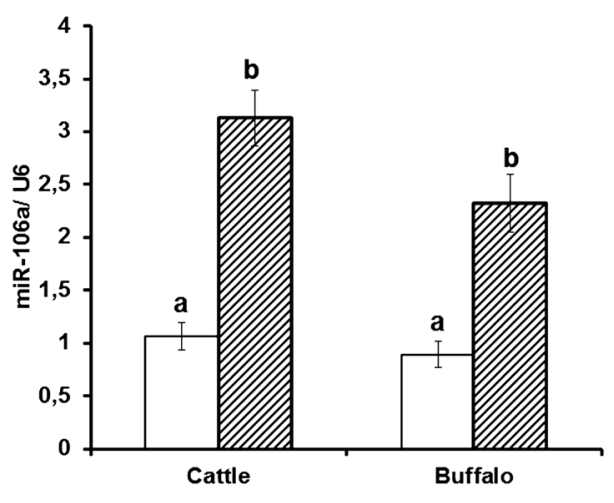

D

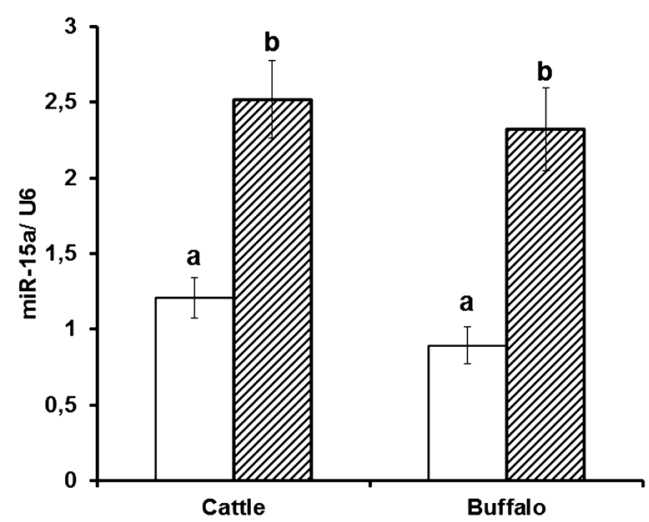

Fig. 3. Abundance of different miRNAs in cultured granulosa cells from buffalo and cattle at different plating densities. miR-378 (A), miR-106 (B) and miR-15a (D) showed significantly higher abundance in high(filled columns) compared with low-density (empty columns) cultures, whereas let-7f (C) was only increased in buffalo. miRNA abundance is indicated relative to U6 transcripts in granulosa cells plated at high (buffalo and cattle, $5 \times 10^{3}$ cells $/ \mathrm{mm}^{2}$ ) and low density (buffalo, $1 \times 10^{3}$ cells $/ \mathrm{mm}^{2}$; cattle, $0.5 \times 10^{3}$ cells $/ \mathrm{mm}^{2}$, respectively) after 4 days in culture. The data are indicated as mean $\pm \mathrm{SEM}$ of three independent experiments. Different letters indicate significant difference at $\mathrm{P}<0.05$ levels.

abundance of PCNA and CCND2 (encoding cyclin D2) transcripts is associated with reduced proliferative activity [14], and in other bovine and rat models downregulation of PCNA and of cyclins after hCG application has been reported [29, 31]. Furthermore, upregulation of $V N N 2$ and $R G S 2$ transcripts also suggests that a higher plating density can mimic LH effects. It has been shown in several studies that the LH surge induces VNN2 and RGS2 in GCs in vivo and in vitro [5, 6, $8,9,14,32]$. On one hand, these data show that GCs from buffalo and cattle respond in a similar way to the applied culture conditions and on the other hand, these results clearly support the hypothesis [14] that an increased plating density can induce a luteinization-like expression profile, thus mimicking LH surge effects.

\section{Silencing of CYP19A1 in granulosa cells cultured at a high} density might be mediated by miRNA species

To obtain a first hint concerning whether miRNA is involved in differential regulation of CYP19A1 in GCs cultured at a high compared with low plating density, we analyzed three candidate miRNAs, miR-378, let-7f and miR-106a. Previous results [21, 33] showed that miR-378 can downregulate aromatase levels and estradiol secretion in ovarian granulosa cells by binding within the 3'-UTR of CYP19A1 transcripts, thus promoting their degradation. Experimental overexpression of miR-378 clearly decreased the levels of CYP19A1 transcripts. This was also supported by inhibitor application and luciferase reporter gene experiments, thus confirming the negative regulation of CYP19A1 expression by miR-378 [21]. Analogously, overexpression of miR-106a in human trophoblasts inhibited expression of $C Y P 19 A 1$ [33]. In cultured GCs from buffalo and cattle, we observed that the miR-378 and miR-106 levels were significantly higher at an increased plating density. In the case of let-7f, we observed no change in cattle, but did observe a significant increase in buffalo. Accordingly, one or several of these miRNA 
species might be involved in mediating negative effects of a high cell density on CYP19A1 expression in cultured bovine and buffalo GCs. Our results are in line with data of previous studies. In breast cancer cells, Shibahara et al. [22] reported high levels of let-7f, however, at a low plating density, which was correlated with decreased levels of aromatase protein. In MCF-7 and SK-BR-3 cell lines, expression of let-7f and CYP19A1 also showed inverse relations with each other. In the same study, it was demonstrated that let-7f directly binds within

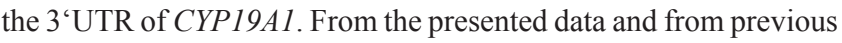
reports, we conclude that in GCs from buffalo and cattle, miR-378 and miR-106a may be involved in the regulation of CYP19A1 gene expression under the present culture conditions.

\section{miRNA might be involved in controlling marker genes of cell} cycle regulation and proliferation in cultured GCs

In buffalo and cattle, miR-15a was significantly upregulated at a high plating density, whereas CCNE1, a putative mi-R15a target, was significantly lower. In previous studies, downregulation of CCNE1 by miR-15a has been clearly demonstrated [25], and it has been reported that inhibition of miR-15a expression increased E2F1mediated CCNE1 expression at transcriptional and translational levels. Consequently, ectopic expression of miR-15a reduced the expression of $C C N E 1$. In addition, it has been reported that let- $7 \mathrm{f}$ is involved in the regulation of chondrocyte proliferation. In chondrocytes, let-7a and let-7f mimic inhibited proliferation, whereas the inhibitory effect of let-7a and let-7f was reversed by its inhibitors. These miRNA species can also reduce proliferation by downregulating the expression of $I G F-1 R$ expression [34]. In a recent study, it was found in human cancer cell lines that miRNA biogenesis is regulated under high-density conditions via the tumor-suppressive Hippo-signalling pathway and the transcriptional coactivator YAP [35]. At low density, YAP is nuclear and represses miRNA synthesis. At a higher cell density, YAP is inactivated by exclusion from the cell nucleus, resulting in enhanced miRNA biogenesis. This mechanism might also be involved in the observed density induced upregulation of miRNA in the present culture model. Future investigations, however, are necessary to prove this hypothesis.

In summary, cultured GCs of buffalo and cattle showed similar regulation of the selected marker transcripts, CYP19A1, PCNA, $C C N E 1, V N N 2$ and $R G S 2$, when comparing low with high plating densities. The reverse regulation of mRNAs and associated miRNAs suggests that density effects on CYP19A1 transcript abundance might be mediated by miR-378, miR106a and let-7f in buffalo, and by miR-378 and miR-106a in cattle. In both species, miR-15a might to be involved in the downregulation of CCNE1 transcript abundance under high-density conditions.

\section{Acknowledgment}

This work was financially supported by N.D.R.I and UGC to Yenuganti Vengala Rao and by an Indo-German DST/DAAD grant (Project-ID 55516734). The authors also thank Veronica Schreiter and Maren Anders for their helping hands during lab work.

\section{References}

1. Mihm M, Bleach EC. Endocrine regulation of ovarian antral follicle development in cattle. Anim Reprod Sci 2003; 78: 217-237. [Medline] [CrossRef]

2. Murphy BD. Luteinization. 2nd ed., Leung PC and Adashi EY (eds.), Burlington MA, Academic Press; 2004:185-199.

3. Milvae RA, Hinckley ST, Carlson JC. Luteotropic and luteolytic mechanisms in the bovine corpus luteum. Theriogenology 1996; 45: 1327-1349. [Medline] [CrossRef]

4. Smith MF, McIntush EW, Smith GW. Mechanisms associated with corpus luteum development. J Anim Sci 1994; 72: 1857-1872. [Medline]

5. Christenson LK, Gunewardena S, Hong X, Spitschak M, Baufeld A, Vanselow J. Research resource: preovulatory LH surge effects on follicular theca and granulosa transcriptomes. Mol Endocrinol 2013; 27: 1153-1171. [Medline] [CrossRef]

6. Sayasith K, Sirois J, Lussier JG. Expression, regulation, and promoter activation of vanin-2 (VNN2) in bovine follicles prior to ovulation. Biol Reprod 2013; 89: 98. [Medline] [CrossRef]

7. Espey LL, Richards JS. Temporal and spatial patterns of ovarian gene transcription following an ovulatory dose of gonadotropin in the rat. Biol Reprod 2002; 67: 1662-1670. [Medline] [CrossRef]

8. Richards JS. Perspective: the ovarian follicle - a perspective in 2001. Endocrinology 2001; 142: 2184-2193. [Medline]

9. Ujioka T, Russell DL, Okamura H, Richards JS, Espey LL. Expression of regulator of G-protein signaling protein-2 gene in the rat ovary at the time of ovulation. Biol Reprod 2000; 63: 1513-1517. [Medline] [CrossRef]

10. Gutiérrez CG, Campbell BK, Webb R. Development of a long-term bovine granulosa cell culture system: induction and maintenance of estradiol production, response to follicle-stimulating hormone, and morphological characteristics. Biol Reprod 1997; 56: 608-616. [Medline] [CrossRef]

11. Klipper E, Levit A, Mastich Y, Berisha B, Schams D, Meidan R. Induction of endothelin-2 expression by luteinizing hormone and hypoxia: possible role in bovine corpus luteum formation. Endocrinology 2010; 151: 1914-1922. [Medline] [CrossRef]

12. Meidan R, Girsh E, Blum O, Aberdam E. In vitro differentiation of bovine theca and granulosa cells into small and large luteal-like cells: morphological and functional characteristics. Biol Reprod 1990; 43: 913-921. [Medline] [CrossRef]

13. Portela VM, Zamberlam G, Price CA. Cell plating density alters the ratio of estrogenic to progestagenic enzyme gene expression in cultured granulosa cells. Fertil Steril 2010; 93: 2050-2055. [Medline] [CrossRef]

14. Baufeld A, Vanselow J. Increasing cell plating density mimics an early post-LH stage in cultured bovine granulosa cells. Cell Tissue Res 2013; 354: 869-880. [Medline] [CrossRef]

15. Bartel DP. MicroRNAs: genomics, biogenesis, mechanism, and function. Cell 2004; 116: 281-297. [Medline] [CrossRef]

16. Gonzalez G, Behringer RR. Dicer is required for female reproductive tract development and fertility in the mouse. Mol Reprod Dev 2009; 76: 678-688. [Medline] [CrossRef]

17. Hong X, Luense LJ, McGinnis LK, Nothnick WB, Christenson LK. Dicer1 is essential for female fertility and normal development of the female reproductive system. Endocrinology 2008; 149: 6207-6212. [Medline] [CrossRef]

18. Nagaraja AK, Andreu-Vieyra C, Franco HL, Ma L, Chen R, Han DY, Zhu H, Agno JE, Gunaratne PH, DeMayo FJ, Matzuk MM. Deletion of Dicer in somatic cells of the female reproductive tract causes sterility. Mol Endocrinol 2008; 22: 2336-2352. [Medline] [CrossRef]

19. Lei L, Jin S, Gonzalez G, Behringer RR, Woodruff TK. The regulatory role of Dicer in folliculogenesis in mice. Mol Cell Endocrinol 2010; 315: 63-73. [Medline] [CrossRef]

20. Yao G, Yin M, Lian J, Tian H, Liu L, Li X, Sun F. MicroRNA-224 is involved in transforming growth factor-beta-mediated mouse granulosa cell proliferation and granulosa cell function by targeting Smad4. Mol Endocrinol 2010; 24: 540-551. [Medline] [CrossRef]

21. Xu S, Linher-Melville K, Yang BB, Wu D, Li J. Micro-RNA378 (miR-378) regulates ovarian estradiol production by targeting aromatase. Endocrinology 2011; 152: 3941 3951. [Medline] [CrossRef]

22. Shibahara Y, Miki Y, Onodera Y, Hata S, Chan MS, Yiu CC, Loo TY, Nakamura Y, Akahira J, Ishida T, Abe K, Hirakawa H, Chow LW, Suzuki T, Ouchi N, Sasano H. Aromatase inhibitor treatment of breast cancer cells increases the expression of let-7f, a microRNA targeting CYP19A1. J Pathol 2012; 227: 357-366. [Medline] [CrossRef]

23. Cimmino A, Calin GA, Fabbri M, Iorio MV, Ferracin M, Shimizu M, Wojcik SE, Aqeilan RI, Zupo S, Dono M, Rassenti L, Alder H, Volinia S, Liu CG, Kipps TJ, Negrini M, Croce CM. miR-15 and miR-16 induce apoptosis by targeting BCL2. Proc Natl Acad Sci USA 2005; 102: 13944-13949. [Medline] [CrossRef]

24. Calin GA, Dumitru CD, Shimizu M, Bichi R, Zupo S, Noch E, Aldler H, Rattan S, Keating M, Rai K, Rassenti L, Kipps T, Negrini M, Bullrich F, Croce CM. Frequent deletions and down-regulation of micro- RNA genes miR15 and miR16 at 13q14 in 
chronic lymphocytic leukemia. Proc Natl Acad Sci USA 2002; 99: 15524-15529. [Medline] [CrossRef]

25. Ofir M, Hacohen D, Ginsberg D. MiR-15 and miR-16 are direct transcriptional targets of E2F1 that limit E2F-induced proliferation by targeting cyclin E. Mol Cancer Res 2011; 9: 440-447. [Medline] [CrossRef]

26. Monga R, Sharma I, Datta TK, Singh D. Characterization of serum-free buffalo granulosa cell culture and analysis of genes involved in terminal differentiation from FSH- to LH-responsive phenotype. Domest Anim Endocrinol 2011; 41: 195-206. [Medline] [CrossRef]

27. Sharma I, Singh D. Conjugated linoleic acids attenuate FSH- and IGF1-stimulated cell proliferation; IGF1, GATA4, and aromatase expression; and estradiol-17 $\beta$ production in buffalo granulosa cells involving PPAR $\gamma$, PTEN, and PI3K/Akt. Reproduction 2012; 144: 373-383. [Medline] [CrossRef]

28. Voss AK, Fortune JE. Levels of messenger ribonucleic acid for cholesterol side-chain cleavage cytochrome P-450 and 3 beta-hydroxysteroid dehydrogenase in bovine preovulatory follicles decrease after the luteinizing hormone surge. Endocrinology 1993; 132: 888-894. [Medline]

29. Nimz M, Spitschak M, Schneider F, Fürbass R, Vanselow J. Down-regulation of genes encoding steroidogenic enzymes and hormone receptors in late preovulatory follicles of the cow coincides with an accumulation of intrafollicular steroids. Domest Anim Endocri- nol 2009; 37: 45-54. [Medline] [CrossRef]

30. Hall PA, Levison DA. Review: assessment of cell proliferation in histological material. $J$ Clin Pathol 1990; 43: 184-192. [Medline] [CrossRef]

31. Robker RL, Richards JS. Hormone-induced proliferation and differentiation of granulosa cells: a coordinated balance of the cell cycle regulators cyclin D2 and p27Kip1. Mol Endocrinol 1998; 12: 924-940. [Medline] [CrossRef]

32. Wu YL, Chuang HH, Kou YR, Lee TS, Lu SH, Huang YC, Nishi Y, Yanase T. Regulation of LH receptor and PGF2alpha receptor signaling by the regulator of $\mathrm{G}$ protein signaling 2 (RGS2) in human and mouse granulosa cells. Chin J Physiol 2008; 51: 282-291. [Medline]

33. Kumar P, Luo Y, Tudela C, Alexander JM, Mendelson CR. The c-Myc-regulated microRNA-17 92 (miR-17 92) and miR-106a 363 clusters target hCYP19A1 and hGCM1 to inhibit human trophoblast differentiation. Mol Cell Biol 2013; 33: 1782-1796. [Medline] [CrossRef]

34. Hu W, Li T, Hu R, Wu L, Li M, Meng X. MicroRNA let-7a and let-7f as novel regulatory factors of the sika deer (Cervus nippon) IGF-1R gene. Growth Factors 2014; 32: 27-33 [Medline] [CrossRef]

35. Mori M, Triboulet R, Mohseni M, Schlegelmilch K, Shrestha K, Camargo FD, Gregory RI. Hippo signaling regulates microprocessor and links cell-density-dependent miRNA biogenesis to cancer. Cell 2014; 156: 893-906. [Medline] [CrossRef] 